\title{
Yield Responses of Direct-Seeded Wheat to Rhizobacteria and Fungicide Seed Treatments
}

\author{
R. James Cook, Scientist, Department of Plant Pathology, and David M. Weller, Research Plant Pathologist, U.S. \\ Department of Agriculture, Agricultural Research Service, Washington State University, Pullman 99164; Adel \\ Youssef El-Banna, Professor, Department of Crops, Zagazig University, Zagazig, Egypt; Dan Vakoch, Program- \\ mer, and Hao Zhang, Assistant Professor, Program in Statistics, Washington State University, Pullman 99164
}

\begin{abstract}
Cook, R. J., Weller, D. M., Youssef El-Banna, A., Vakoch, D., and Zhang, H. 2002. Yield responses of direct-seeded wheat to rhizobacteria and fungicide seed treatments. Plant Dis. 86:780-784.

Field trials were conducted with winter and spring wheat in eastern Washington and northern Idaho over several years to determine the benefit, as measured by grain yield, of seed treatments with rhizobacteria and formulated fungicides in cropping systems favorable to root diseases. The trials were conducted with wheat direct-seeded (no-till) in fields with a history of intensive cereals and one or more of the root diseases: take-all caused by Gaeumannomyces graminis var. tritici, Rhizoctonia root rot caused by Rhizoctonia solani AG8 and $R$. oryzae, and Pythium root rot caused mainly by Pythium irregulare and $P$. ultimum. The seed treatments included Bacillus sp. L324-92, Pseudomonas fluorescens Q69c-80, Pseudomonas fluorescens Q8r1-96, difenoconazole + metalaxyl (Dividend + Apron), difenoconazole + mefenoxam (Dividend + Apron XL $=$ Dividend XL), tebuconazole + metalaxyl $($ Raxil XT), and tebuconazole + thiram (Raxil-thiram). Controls were nontreated seed planted into both nontreated (natural) soil and soil fumigated with methyl bromide just prior to planting. Although the data indicate a trend in higher wheat yields with two rhizobacteria treatments over the nontreated control (171 and $264 \mathrm{~kg} / \mathrm{ha}$, respectively), these higher yields were not significantly different from the nontreated control $(P=0.06)$. Fungicide seed treatments alone similarly resulted in yields that were 100 to $300 \mathrm{~kg} / \mathrm{ha}$ higher than the nontreated control, but only the yield responses to Dividend on winter wheat $(289 \mathrm{~kg} / \mathrm{ha})$ and Dividend + Apron on spring wheat $(263 \mathrm{~kg} / \mathrm{ha})$ were significant $(P \leq$ $0.05)$. The greatest yield increases over the nontreated control occurred with certain rhizobacteria-fungicide combinations, with three treatments in the range of 312 to $486 \mathrm{~kg} / \mathrm{ha}(6.1$ to $17.7 \% ; P \leq 0.05)$. Some rhizobacteria-fungicide combinations brought average yields to within 85 to $90 \%$ of those obtained with soil fumigation. Only soil fumigation produced a measurable reduction in the incidence of take-all and Rhizoctonia root rot, as assessed on washed roots. No reliable method exists for visual quantification of Pythium root rot on wheat.
\end{abstract}

Additional keywords: no-till, soilborne pathogens

Root diseases, particularly take-all caused by Gaeumannomyces graminis (Sacc.) von Arx \& Olivier var. tritici Walker, Rhizoctonia root rot caused by Rhizoctonia solani Kühn AG8 and $R$. oryzae Ryker \& Gooch, and Pythium root rot caused by several Pythium species but mainly $P$. irregulare Buisman and $P$. ultimum Trow., are widespread on wheat (Triticum aestivum L.) and barley (Hordeum vulgare L.) in the U.S. Pacific Northwest (PNW). These diseases remain

Corresponding author: R. James Cook

E-mail: rjcook@wsu.edu

PPNS No. 0327, Department of Plant Pathology, College of Agriculture and Home Economics Research Center, Project No. 3061-4945, Washington State University, Pullman 99164-6430.

Accepted for publication 24 February 2002.

Publication no. D-2002-0422-03R

() 2002 The American Phytopathological Society which these treatments also protect plants against root infections is mostly a matter of conjecture. Further, most research on seed treatments evaluates performance based on stands or disease incidence, but little has been done to determine the benefits of seed treatments in terms of yields in systems agronomically similar to modern, dryland, wheat-intensive cropping systems. Smiley and Patterson (16) reported a 5\% (185 $\mathrm{kg} / \mathrm{ha}$ ) increase in grain yield for winter wheat grown in eastern Oregon in response to seed treatments intended mainly for smut control, namely Vitavax (carboxin) and Dividend (difenoconazole). Such a yield increase represents four- to fivefold return on the investment, even with wheat selling for less than US $\$ 100 / \mathrm{mt}$, but is still well short of yield increases demonstrated from either soil fumigation or a 3-year winter wheat/spring barley/pea rotation (2-6).

Seed treatment fungicides currently available for use on cereals have systemic activity but apparently do not move downward into the roots. In contrast, strains of Bacillus and Pseudomonas species, selected for both rhizosphere competence (17) and ability to provide biological control of take-all (18), Rhizoctonia root rot (9), and Pythium root rot $(1,19)$, have the ability to grow downward with elongating roots from a seed-applied source of inoculum (17). The objective of this research was to determine the benefit, as measured by an increase in grain yield, of select strains of rhizobacteria (11) applied alone and in combination with commercially available fungicides for root disease control in cropping systems characterized by intensive cereals with reduced or no tillage prior to planting.

\section{MATERIALS AND METHODS}

Locations and field histories. Twentyfour field trials were conducted during 1993 to 1999 at five locations in eastern Washington and adjacent northern Idaho. The five locations were the Steve Matsen farm near Bickleton, Klickatat Co., WA; the Robert Wigen farm near Dusty, Whitman Co., WA; the John Aeschliman farm near Colfax, Whitman Co., WA; the U.S. Department of Agriculture Palouse Conservation Field Station near Pullman, Whitman Co., WA; and the Nelson Bros. farm near Troy, Latah Co., ID (Table 1). The annual precipitation averages about 
30, 40, 45, 50, and $55 \mathrm{~cm}$ for the Bickleton, Dusty, Colfax, Pullman, and Troy sites, respectively. Typical of PNW dryland farming systems, no supplemental irrigation was used. The fields used for tests at the Bickleton, Colfax, and Pullman sites each had a history of continuous directseeded cereals for 5 years or longer. The fields near Dusty were direct-seeded for the first or second time after a long history of winter wheat planted conventionally into conventionally tilled fallow (2-year wheat/fallow rotation). The fields near Troy were in a 2-year rotation of winter wheat/lentils, typical of northern Idaho and adjacent northeastern Washington, and were direct-seeded for the first time after decades of conventional tillage. Tests at the Bickleton and Colfax sites were conducted in different fields of similar histories, usually winter wheat seeded directly into spring wheat stubble and spring wheat seeded directly into winter wheat stubble; this permitted tests with both spring and winter wheat each year. Tests at the Troy sites were also carried out in different fields of the same cropping history. Tests at the Dusty site all were with spring wheat planted into winter wheat stubble, in different fields each year. The tests conducted on the Palouse Conservation Field Station in 1996 to 1999 were on the same site each year, which was alternated between spring and winter wheat.

Varieties. All tests were conducted with either soft white spring wheat or soft white winter wheat, the two predominant kinds of wheat grown in the Pacific Northwest. The spring wheat variety was Penawawa through 1996 and Alpowa starting in 1997. Wawaiwai was used in place of Alpowa in 1999 at the Bickleton site because of its resistance to Hessian fly that rendered the 1998 yield results for Alpowa at this location unusable. The variety Madsen was used for all tests with winter wheat. In addition to Madsen, the test at Bickleton in 1999 also included seed treatments on the soft white winter wheat variety Eltan. All tests were carried out with current-year (i.e., fresh) certified seed (8).

Methods of seed treatment. Bacterial strains used in this study were Bacillus sp. L324-92 (10), Pseudomonas fluorescens Q69c-80 (12), and P. fluorescens Q8r1-96 (13). Wheat seeds were treated with bacteria as described by Pierson and Weller (12). Bacteria stored in glycerol at $-20^{\circ} \mathrm{C}$ or $-80^{\circ} \mathrm{C}$ were removed from storage and cultured on nutrient broth yeast extract agar (NBY) for 2 days at $27^{\circ} \mathrm{C}$. The bacteria from these plates were then suspended in sterile, deionized water, and $1.0-\mathrm{ml}$ aliquots of the suspension were introduced onto plates of King's medium B (KMB) (10). Cultures were incubated for 2 to 3 days at room temperature and the bacteria then scraped from the plates and suspended in a $1.0 \%$ (L324-92 and Q69c-80) or $0.5 \%$ (Q8r1-96) suspension (wt/vol) of methyl cellulose (Sigma Chemical Co., St. Louis, MO). The bacterial suspension was applied uniformly to the seed as a slurry with thorough mixing in a glass beaker. Treated seeds were dried overnight under a stream of filtered air in a laminar flow hood. Dosages used throughout the study were approximately $5 \times 10^{6}$ for L 324-92, $10^{7}$ to $10^{8}$ for Q69c-80, and $10^{4}$ to $10^{5}$ for Q8r196.

The formulated fungicides used for the seed treatments were difenoconazole + metalaxyl (Dividend + Apron, Syngenta Crop Protection, Greensboro, NC), difenoconazole + mefenoxam (Dividend + Apron $\mathrm{XL}=$ Dividend XL, Syngenta), tebuconazole + thiram (Raxil-thiram, Gustafson LLC, Dallas, TX), and tebuconazole + metalaxyl (Raxil XT, Gustafson LLC).

All fungicide formulations were applied to the seed according to the manufacture's specifications at standard recommended rates. These rates as product per $\mathrm{kg}$ of seed were: $0.33 \mathrm{ml}$ of Dividend and $1.2 \mathrm{ml}$ of Apron for Dividend + Apron; $0.65 \mathrm{ml}$ of Dividend XL; $2.3 \mathrm{ml}$ of Raxil-thiram; and $0.01 \mathrm{~g}$ of Raxil XT. The amount of product needed to treat $10 \mathrm{~kg}$ of seed was mixed with $200 \mathrm{ml}$ of water, and this solution was then added slowly as a slurry to seed in a rotating drum. The uniformly treated seed was spread as a thin layer on clean paper overnight for drying and then transferred to a paper bag left open at the top until the time of planting, usually within 24 to $48 \mathrm{~h}$ after treatment. For tests conducted with Raxil-thiram and Raxil XT during the years 1997, 1998, and 1999, seed was treated by the manufacturer and returned by overnight mail within 1 or 2 days of planting. The same seed was held back for planting the nontreated controls.
For combinations of rhizobacteria and fungicide treatments, the desired rhizobacteria or fungicide mixture was mixed at the desired rate with the bacterial suspension in methyl cellulose and applied to the seed in the same way used to apply the rhizobacteria alone. Each combination treatment included the appropriate controls of rhizobacteria and fungicide treatments alone and a nontreated control, all with the same variety and seed lot.

Plot design and methods of soil fumigation, fertilization, and planting. All trials were randomized complete block designs with either four (Dusty, Pullman, and Troy locations) or six (Bickleton and Colfax) replicates per treatment. Each plot was $2.3 \times 8 \mathrm{~m}$. Plots intended for soil fumigation were located within each experimental layout, trenched around their perimeters, covered with 6-mil clear plastic tarp, and fumigated with methyl bromide at $45 \mathrm{~g} / \mathrm{m}^{2}$ (4). The tarps were removed and the trial was planted 2 or 3 days after fumigation. Each trial was planted directly (no-till) into the undisturbed soil and standing stubble of the previous crop, which was either wheat (Bickleton, Colfax, Dusty, and Pullman sites) or lentil residue (Troy site). A burn-down herbicide (glyphosate $=$ Roundup) was applied at least 2 weeks and more commonly 1 month or longer before planting wheat after wheat to eliminate volunteer and grass weed hosts of the root pathogens $(14,15)$.

The drill used to plant the trials was described by Cook and Haglund (4) and Cook et al. (5). Briefly, it is equipped to place fertilizer as a liquid mixture of nitrogen, phosphorus, and sulfur (NPS) directly beneath the seed at the time of planting in eight rows spaced uniformly at $30 \mathrm{~cm}(2.3$

Table 1. Average yields of spring and winter wheats at the indicated years and locations with and without (control) soil fumigation

\begin{tabular}{|c|c|c|c|c|c|}
\hline \multirow[b]{2}{*}{ Location } & \multirow[b]{2}{*}{ Year } & \multicolumn{2}{|c|}{ Spring wheat } & \multicolumn{2}{|c|}{ Winter wheat } \\
\hline & & $\begin{array}{c}\begin{array}{c}\text { Control } \\
\text { (kg/ha) }\end{array} \\
\end{array}$ & $\begin{array}{c}\text { Fumigated }^{\text {a }} \\
(\mathrm{kg} / \mathrm{ha})\end{array}$ & $\begin{array}{c}\text { Control }^{\mathbf{a}} \\
(\mathbf{k g} / \mathbf{h a})\end{array}$ & $\begin{array}{c}\text { Fumigated } \\
\text { (kg/ha) }\end{array}$ \\
\hline \multirow[t]{3}{*}{ Bickleton, WA } & 1998 & 1,438 & & 2,632 & 4,077 \\
\hline & 1999 & 2,556 & & 2,584 & 3,237 \\
\hline & 2000 & 1,910 & & 2,362 & 3,550 \\
\hline \multirow{3}{*}{ Dusty, WA } & 1993 & 3,202 & 3,813 & & \\
\hline & 1994 & 2,570 & 3,577 & & \\
\hline & 1996 & 2,500 & 2,473 & & \\
\hline \multirow[t]{6}{*}{ Colfax, WA } & 1993 & & & 5,869 & 5,230 \\
\hline & 1995 & & & 4,369 & 5,987 \\
\hline & 1996 & 3,521 & & 6,383 & 7,335 \\
\hline & 1997 & 4,271 & 6,848 & 5,036 & 6,786 \\
\hline & 1998 & 3,188 & 4,223 & 5,459 & 5,550 \\
\hline & 1999 & 4,160 & 5,348 & 3,730 & 5,758 \\
\hline \multirow{4}{*}{ Pullman, WA } & 1996 & & & 6,063 & \\
\hline & 1997 & 4,806 & & & \\
\hline & 1998 & & & 5,709 & \\
\hline & 1999 & 4,438 & & & \\
\hline \multirow[t]{3}{*}{ Troy, ID } & 1994 & & & 6,945 & \\
\hline & 1995 & & & 5,737 & \\
\hline & 1996 & & & 5,925 & \\
\hline Average & & 3,213 & 4,380 & 4,914 & 5,279 \\
\hline
\end{tabular}

${ }^{\mathrm{a}}$ Each value is the average yield for four (Dusty, Pullman, and Troy) or six (Bickleton and Colfax) replicates, where individual plots were $2.3 \times 8 \mathrm{~m}$. 
$\mathrm{m}$ total width per plot). The rates of $\mathrm{N}, \mathrm{P}$, and $\mathrm{S}$ were set for each location based on a commercially available soil test and yield goal for that site and year following standard industry recommendations (7). These rates of $\mathrm{N}, \mathrm{P}$, and $\mathrm{S}$ were typically in the range of 60,20 , and $10 \mathrm{~kg} / \mathrm{ha}$, respectively, for the low precipitation areas (e.g., Bickleton), 120, 40, and $10 \mathrm{~kg} / \mathrm{ha}$, respectively, for the high-precipitation areas (e.g., Pullman and Troy), and proportionally intermediate for the intermediate-precipitation areas (e.g., Dusty and Colfax). Exact rates varied with the amount of residual $\mathrm{N}, \mathrm{P}$, and $S$ and percentage of organic matter at the respective sites (7). The drill is also equipped with a cone designed to deliver all the seed of any given treatment within a predetermined length of plot, which in these trials was $8 \mathrm{~m}$. Nontreated seed was planted in the fumigated plots.

Yield determinations. All plots were harvested with a Wintersteiger Nursery Master plot combine (Wintersteiger, Salt Lake City, UT). Each 8-m-long plot was trimmed to $7 \mathrm{~m}$ by mowing $50 \mathrm{~cm}$ off each end, and then five of the eight rows were harvested with borders of one row and two rows, respectively, on the two sides of each plot. The grain was cleaned and weighed to determine the yields on the basis of 12 to $13 \%$ grain moisture.

Assessment of root diseases. A representative sample of plants taken during mid-May to mid-June (Feekes stages 6 to 8 [7], which varied from year to year) was assessed for the incidence of Rhizoctonia root rot and take-all in both 1996 and 1998. No reliable method is available to quantitatively rate wheat roots for incidence or severity of Pythium root rot. Plants were dug from approximately $15 \mathrm{~cm}$ of row at each of five places in each plot, shaken gently to remove the loose soil, and then bulked in a new plastic bag for transport to the laboratory and storage at $4^{\circ} \mathrm{C}$ (if necessary) before processing. The roots on these plants were thoroughly washed under a high-pressure stream of water and then 15 plants were selected randomly from each bulk sample for assessment. The measurements included: (i) length of the mainstem (pseudostem), measured from the crown to the tip of the longest leaf; (ii) number of seminal roots; and (iii) number of seminal roots with Rhizoctonia root rot and take-all lesions. Where a single root had lesions characteristic of both diseases, the same root was counted as positive for both diseases.

Statistical analysis. Significant seedtreatment effects were identified with the Means Procedure of Windows SAS version 6.12 using the Windows NT operating system. By this procedure, the yield for each replicate of each seed treatment of each test was subtracted from the mean yield of the nontreated (control) for each test to obtain a mean yield increase or decrease in response to that treatment. If there was no seed treatment effect, the resultant mean difference would be no yield change. The percent difference from the yield for nontreated seed planted into nontreated soil (control) was calculated by dividing the difference between the seed treatment and this control by the average yield of this control for each plot.

Data on length of the mainstem, total number of seminal roots, and percentage of seminal roots with lesions characteristic of Rhizoctonia root rot and take-all were analyzed by ANOVA using SAS, and significantly different treatments were identified by Fisher's protected LSD method at $P=0.05$.

\section{RESULTS}

General performance of crops at different sites. As expected, yields at each location each year were lowest at Bickleton (the driest location) and progressively higher with increasing annual rainfall (Dusty, Colfax, Pullman, Troy locations) (Table 1). Also typical of the two kinds of wheat, spring wheat yields averaged only about $65 \%$ of the yields of winter wheat (Table 1).

Failure to effectively control volunteer spring wheat in the winter wheat made it necessary to abandon the Colfax site in 1994 and made the data unusable for the statistical analysis at the Bickleton, Colfax, and Pullman sites in 1998 (Table 1). In addition, one or more individual plots was lost due to damage from rodents. Yield data from these plots likewise were dropped from the analyses, reducing the number of replicates for certain treatments. Similarly, an outbreak of Hessian fly on the spring wheat at Bickleton in 1999 precluded the use of these yield data in the statistical analysis.

Yield responses to soil fumigation. Combining the data across all tests (Table 2 ), the yields in response to soil fumigation were approximately $1,000 \mathrm{~kg} / \mathrm{ha}$ higher for spring wheat and $900 \mathrm{~kg} / \mathrm{ha}$ higher for winter wheat compared with nontreated seed planted in nontreated soil, both significant at $P=0.01$. Actual yields for nontreated seed in either nonfumigated or fumigated soil for the different years and sites are given in Table 1 . The yield depression in response to fumigation at the Colfax site in 1993 (Table 1) was associated with an acute leaf necrosis starting about the heading stage specifically in the plots treated with methyl bromide. This necrosis occurred after an obvious increased growth response of the winter wheat to the fumigation of these plots. Fumigated plots at the Troy site in 1994 showed extremely severe injury from the methyl bromide treatment, such that this

Table 2. Yield changes (+/-) from a nontreated control in response to soil fumigation and seed treatments for spring and winter wheats at five locations (Bickleton, Dusty, Colfax, and Pullman, WA, and Troy, ID) over the years 1993 to 1996

\begin{tabular}{|c|c|c|c|c|c|c|c|c|}
\hline \multirow[b]{2}{*}{ Treatment } & \multicolumn{4}{|c|}{ Spring wheat } & \multicolumn{4}{|c|}{ Winter wheat } \\
\hline & $\%^{a}$ & $(\text { No. })^{\mathbf{b}}$ & $\mathbf{k g} / \mathbf{h a}^{\mathrm{c}}$ & $P$ value ${ }^{d}$ & $\%^{a}$ & $(\text { No. })^{\mathbf{b}}$ & $\mathbf{k g} / \mathbf{h a}^{\mathrm{c}}$ & $P$ value $^{\mathrm{d}}$ \\
\hline Fumigation (methyl bromide) & 32 & 35 & 1,049 & $<0.01$ & 24 & 39 & 907 & $<0.01$ \\
\hline Dividend & -3.6 & 23 & -92 & 0.56 & 5.2 & 43 & 289 & 0.01 \\
\hline Dividend + Apron & 8.1 & 20 & 263 & 0.03 & 3.1 & 32 & 191 & 0.10 \\
\hline Dividend XL & -0.8 & 16 & -26 & 0.91 & 4.0 & 26 & 153 & 0.10 \\
\hline Raxil-thiram & 4.6 & 21 & 268 & 0.31 & 6.6 & 12 & 301 & 0.16 \\
\hline Raxil XT & 5.7 & 16 & 167 & 0.32 & 9.5 & 33 & 219 & 0.13 \\
\hline L324-96 & 5.4 & 54 & 171 & 0.06 & 2.0 & 49 & 76 & 0.49 \\
\hline L324-96 + Dividend & & & & & 6.1 & 31 & 312 & 0.01 \\
\hline L324-96 + Dividend XL & 1.1 & 16 & 20 & 0.93 & 10.2 & 12 & 328 & 0.11 \\
\hline L324-96 + Raxil-thiram & -6.0 & 11 & -278 & 0.24 & 5.0 & 17 & 230 & 0.21 \\
\hline L324-96 + Raxil XT & & & & & 9.8 & 12 & 314 & 0.27 \\
\hline Q69c-80 & 3.2 & 28 & 37 & 0.81 & 1.2 & 49 & 82 & 0.35 \\
\hline Q69c-80 + Dividend & 17.7 & 8 & 486 & $<0.01$ & 8.4 & 23 & 438 & $<0.01$ \\
\hline Q8r1-96 & 5.6 & 11 & 187 & 0.52 & 6.2 & 21 & 264 & 0.06 \\
\hline Q8r1-96 + Dividend XL & & & & & 15.2 & 12 & 479 & 0.05 \\
\hline Q8r1-96 + Raxil-thiram & & & & & 5.6 & 22 & 293 & 0.07 \\
\hline
\end{tabular}

\footnotetext{
${ }^{a}$ Percent change in grain yield from nontreated control.

${ }^{\mathrm{b}}$ Number of paired comparisons.

${ }^{c}$ Actual change in grain yield compared to nontreated control.

${ }^{\mathrm{d}} P$ value based on a $t$ test that compared the treated with its corresponding nontreated control for each year, location, and replicate.
} 
treatment was discontinued at this location. No such damage was observed at the other locations, although it has been observed in other studies within this region (5).

Yield responses to the rhizobacteria seed treatments. Two rhizobacteria treatments used alone produced a trend of higher wheat yields compared with the nontreated control, but the differences were not significant. Yields in response to Bacillus sp. L324-92 were $171 \mathrm{~kg} / \mathrm{ha}$ higher than the nontreated control (Table 1), but this difference was not significant $(P=0.06)$. Likewise, yields in response to $P$. fluorescens Q8r1-96 were $264 \mathrm{~kg} / \mathrm{ha}$ higher than the nontreated control (Table 1), but this difference was not significant $(P=0.06)$.

Yield responses to the fungicide seed treatments. With the exceptions of Dividend and Dividend XL on spring wheat, all fungicide seed treatments resulted in a yield response in the range of 3 to $8 \%$ (100 to $300 \mathrm{~kg} / \mathrm{ha}$ ) greater yield compared with the nontreated control (Table 2). Only the yield responses to Dividend on winter wheat and Dividend + Apron on spring wheat were significant $(P<0.05)$.

Yield responses to rhizobacteria + fungicide seed treatments. The greatest yield responses to the seed treatments occurred with combinations of rhizobacteria and fungicides (Table 2). Yields were higher than the nontreated control by $6.1 \%$ $(P=0.01)$ in response to strain L-324-92 combined with Dividend. Yields in response to Q69c-80 combined with Dividend were $17.7 \%$ higher than the nontreated control for spring wheat $(P<$ 0.01 ) and $8.4 \%$ higher than the nontreated control for winter wheat $(P<0.01)$. The combination of Q8r1-96 and Dividend XL produced a $15.2 \%$ higher yield $(P=0.05)$.

Root disease assessments. Assessment of Rhizoctonia root rot and take-all revealed remarkably uniform amounts of these diseases (Table 3), with the least take-all at the driest sites (e.g., Bickleton and spring wheat at Colfax). However, in both 1996 (data not shown) and 1998, only soil fumigation resulted in a significant reduction in the incidence of these two diseases on the seminal roots compared with the nontreated control (Table 3). Further, with the exception of L324-92 on winter wheat at Colfax in 1998, only soil fumigation produced an increased growth response as measured by length of the mainstem compared with the same nontreated seed planted into nontreated soil. Two seed treatments, namely L324-92 + Raxil-thiram on spring wheat at Colfax and Raxil-thiram alone on winter wheat at Pullman resulted in an increase $(28.1 \%$ compared with $18.5 \% ; P<0.05)$ in lesions characteristic of Rhizoctonia root rot (Table 3). Raxil-thiram also resulted in a decrease $(9.9 \%$ compared with $15.9 \% ; P<$ 0.05 ) in the incidence of seminal roots with Rhizoctonia lesions on winter wheat at the Colfax site.

\section{DISCUSSION}

Clearly, seed treatments with certain commercially available formulations of fungicides are worth the investment as a means to raise yields of both spring and winter wheat more nearly to the full potential of these crops when grown intensively in direct-seed systems. Although highly variable, average yield responses in the range of 263 to $289 \mathrm{~kg} / \mathrm{ha}$, e.g., Dividend + Apron on spring wheat and Dividend on winter wheat, over the diversity of locations and years provides a gross return to the grower of $\$ 25$ to $\$ 30 /$ ha $(\$ 10$ to $\$ 12 / \mathrm{A})$. These returns are several times the cost of the fungicides and their application to the seed. These yield responses are similar to or slightly greater than the increases reported by Smiley and Patterson (16) for carboxin (Vitavax) and difenoconazole (Dividend) on winter wheat grown with conventional tillage and seeding in Oregon.

All yield increases in response to the fungicide seed treatments fall far short of the potential yields as indicated by the yields achieved when the soil was treated with methyl bromide just prior to planting. The yield increase in response to soil fumigation averaged 35 and $24 \%$ greater than the nontreated controls for spring and winter wheat, respectively. Even the "best" yield increase in response to a fungicide seed treatment, e.g., $8.1 \%$ average yield response of spring wheat to Dividend + Apron, is only $80 \%$ of the potential for spring wheat as revealed by soil fumiga-

Table 3. Influence of rhizobacteria and fungicide seed treatments, soil fumigation, and no seed treatments (controls) on wheat growth (length of mainstem and number of seminal roots) and percentage of seminal roots with lesions of Rhizoctonia root rot or take-all in 1998

\begin{tabular}{|c|c|c|c|c|}
\hline Treatments & $\begin{array}{c}\text { Mainstem } \\
\text { length }^{\mathrm{a}}(\mathrm{cm})\end{array}$ & $\begin{array}{l}\text { Seminal roots } \\
\text { (no./plant) }\end{array}$ & $\begin{array}{c}\text { \% seminal roots } \\
\text { with Rhizoctonia } \\
\text { root rot }^{\mathrm{b}}\end{array}$ & $\begin{array}{c}\% \text { seminal } \\
\text { roots with } \\
\text { take-all lesions }\end{array}$ \\
\hline \multicolumn{5}{|l|}{ Winter wheat, Bickleton } \\
\hline Control & 52.0 & 3.5 & 14.6 & 0.6 \\
\hline Fumigated soil & 59.5 & 3.7 & 4.4 & 0.0 \\
\hline L324-92 & 51.2 & 3.7 & 17.6 & 0.0 \\
\hline L324-92 + Dividend/Apron & 51.8 & 3.6 & 14.1 & 0.4 \\
\hline L324-92 + Raxil-thiram & 53.5 & 3.5 & 11.3 & 0.6 \\
\hline Q8r1 & 54.2 & 3.6 & 14.8 & 1.5 \\
\hline Q8r1 + Dividend/Apron & 52.0 & 3.7 & 14.1 & 0.2 \\
\hline Q8r1 + Raxil-thiram & 53.6 & 3.9 & 11.7 & 0.8 \\
\hline Dividend/Apron & 53.5 & 3.7 & 9.7 & 0.4 \\
\hline Raxil-Thiram & 53.3 & 3.5 & 14.1 & 1.8 \\
\hline $\operatorname{LSD}(P=0.05)$ & 2.3 & 0.2 & 5.4 & 1.3 \\
\hline \multicolumn{5}{|l|}{ Spring wheat, Colfax } \\
\hline Control & 65.7 & 4.76 & 18.5 & 0.0 \\
\hline Fumigated soil & 74.0 & 4.88 & 11.7 & 0.0 \\
\hline L324-92 & 66.2 & 4.90 & 15.9 & 0.0 \\
\hline L324-92 + Dividend XL & 67.5 & 4.30 & 16.1 & 0.3 \\
\hline L324-92 + Raxil-thiram & 65.0 & 4.57 & 28.1 & 0.0 \\
\hline Q8r1-96 & 65.3 & 4.71 & 16.4 & 2.2 \\
\hline Q8r1-96 + Dividend XL & 67.9 & 4.82 & 21.3 & 0.4 \\
\hline Q8r1-96 + Raxil-thiram & 66.7 & 4.71 & 14.2 & 1.5 \\
\hline Dividend XL & 66.8 & 4.67 & 22.9 & 0.5 \\
\hline Raxil-Thiram & 66.6 & 4.74 & 18.3 & 0.0 \\
\hline $\operatorname{LSD}(P=0.05)$ & 2.3 & 0.24 & 5.9 & 1.2 \\
\hline \multicolumn{5}{|l|}{ Winter wheat, Pullman } \\
\hline Control & & 4.6 & 24.1 & 3.1 \\
\hline L324-92 & & 4.9 & 28.5 & 6.1 \\
\hline L324-92 + Dividend/Apron & & 4.6 & 32.7 & 3.0 \\
\hline L324-92 + Raxil-thiram & & 4.5 & 26.6 & 2.0 \\
\hline Dividend/Apron & & 5.1 & 29.4 & 4.3 \\
\hline Raxil-thiram & & 4.8 & 44.6 & 3.4 \\
\hline $\operatorname{LSD}(P=0.05)$ & & 0.4 & 10.1 & 3.4 \\
\hline \multicolumn{5}{|l|}{ Winter wheat, Colfax } \\
\hline Control & 66.8 & 4.6 & 15.9 & 19.0 \\
\hline Fumigated soil & 76.7 & 4.6 & 5.3 & 11.8 \\
\hline L324-92 & 71.9 & 4.7 & 11.1 & 15.2 \\
\hline L324-92 + Dividend/Apron & 62.9 & 4.5 & 11.9 & 19.8 \\
\hline L324-92 + Raxil-thiram & 65.7 & 4.4 & 12.8 & 17.3 \\
\hline Q8r1-96 & 68.1 & 4.3 & 11.2 & 22.2 \\
\hline Q8r1-96 + Dividend/Apron & 60.3 & 4.5 & 11.5 & 21.3 \\
\hline Q8r1-96 + Raxil-thiram & 67.2 & 4.7 & 12.0 & 22.4 \\
\hline Dividend/Apron & 67.1 & 4.6 & 17.0 & 17.4 \\
\hline Raxil-thiram & 68.5 & 4.6 & 9.9 & 17.6 \\
\hline $\operatorname{LSD}(P=0.05)$ & 3.9 & 0.3 & 5.4 & 7.5 \\
\hline
\end{tabular}

a Plants sampled on 19 May 1998 for root rating on 27 May 1998 for Bickleton; 24 June 1998 for spring wheat, Colfax; 19 May 1998 for Pullman; and 21 May 1998 for winter wheat, Colfax. Fifteen plants were harvested from four replicate plots for each treatment.

b Number of seminal roots with Rhizoctonia root rot or take-all lesions divided by total number of seminal roots. 
tion. On the other hand, yields with no seed treatment but using best management practices available for intensive cereals and direct seeding are only about $75 \%$ of the potential for spring wheat and $80 \%$ of the potential for winter wheat.

Of the three rhizobacteria seed treatments, none produced a significant yield increase on either spring or winter wheat when used alone. On the other hand, the $5.4 \%$ yield response of spring wheat to strain L324-92 $(P=0.06)$ and the 6.2\% yield response of winter wheat to strain Q8r1-96 are within the range of yield responses obtained with the best fungicide combination treatments. However, the greatest responses occurred with combinations of rhizobacteria and fungicide seed treatments, especially with treatments containing Dividend. Whereas Q69c-80 by itself had no measurable yield effect, Q69c-80 + Dividend resulted in average yield responses of $17.7 \%$ (486 kg/ha) on spring wheat and $8.4 \%$ (435 kg/ha) on winter wheat, both highly significant $(P=$ 0.01). Similarly, Q8r1-96 + Dividend XL resulted in an average yield response over the nontreated control of $15.2 \%$ (479 $\mathrm{kg} / \mathrm{ha} ; P=0.05$ ). For strain L324-92, the average yield response of winter wheat was $6.1 \%(312 \mathrm{~kg} / \mathrm{ha} ; P=0.01)$ when combined with Dividend. These results are not surprising, considering that root diseases occur as a mixture on wheat in the dryland PNW, and only control of most or all members of the mixture is likely to produce a yield response. Yield responses of 10 and $15 \%$ bring the attainable yields to within 85 to $90 \%$ of the potential for these sites and years as revealed by soil fumigation.

We routinely score seminal roots for take-all and Rhizoctonia root rot since these are the first roots to be exposed to soilborne inoculum of the pathogens and their protection is key to early plant vigor reflected in the length of the mainstem, among other indicators of plant health. However, of all the treatments for which root ratings were made (Table 3 ), only soil fumigation resulted in a consistently lower percentage of seminal roots with symptoms of these root diseases. The incidence of take-all on seminal roots was high enough to detect differences only in the test with winter wheat at Colfax in 1998, but the incidence of roots with Rhizoctonia root rot was high enough to detect differences in all four tests that year. It seems likely that the protocol used to evaluate take-all and Rhizoctonia root rot was not sufficiently sensitive to pick up treatment ef- fects where the corresponding yield response is only 5 to $10 \%$ or where the corresponding increase in length of mainstem in response to seed treatment is only 1 to 2 $\mathrm{cm}$. Length of mainstem is a sensitive indicator of root disease pressure (6). Possibly, a larger sample size would improve ability to detect treatment effects. For example, an average increase of 1 to $2 \mathrm{~cm}$ in length of the mainstem, as occurred in several of the tests with Q8r1-96, might have been statistically significant if a larger number of plants had been evaluated. In addition, we have no visual method by which to rate roots for incidence or severity of Pythium root rot, yet length of the mainstem is a sensitive indicator of the severity of this disease $(4,6)$

The large yield responses to soil fumigation with methyl bromide are consistent with previous results in this region for intensive wheat $(3,5,6)$. A summary of earlier work with soil fumigation revealed an average response of 70,22 , and $7 \%$ greater yields in the PNW for winter wheat planted every year (no break; included some fields under irrigation), every other year (2-year crop rotations), and every third year (3-year crop rotations), respectively (2). Since all but the tests at Troy, ID, were conducted in fields cropped the previous several years to a cereal grain, and based on the average responses of 24 and $35 \%$ for winter and spring wheat, respectively, there is little doubt that the tests for efficacy of the seed treatments were conducted under conditions of high pressure from the root disease complex present in this area. Even the tests conducted at Troy were in fields cropped every other year to winter wheat where, based on earlier tests, we could expect a $22 \%$ average yield response to soil fumigation (6).

\section{ACKNOWLEDGMENTS}

We thank Gustafson LLC, Dallas, TX, and Syngenta Crop Protection, Greensboro, NC, for advice and financial support of this work. We also thank McGregor Co., Colfax, WA, for help with soil tests and fertilizer recommendations; Tim Paulitz, Richard Smiley, Randy Scott, and Kirin Shetty for helpful comments with this manuscript; and Kurt Schroeder and Ron Sloot for technical assistance with the field tests.

\section{LITERATURE CITED}

1. Becker, J. O., and Cook, R. J. 1988. Role of siderophores in suppression of Pythium species and production of increased-growth response of wheat by fluorescent pseudomonads. Phytopathology 78:778-782.

2. Cook, R. J. 1992. Wheat root health management and environmental concern. Can. J. Plant Pathol. 14:76-85.

3. Cook, R. J., and Haglund, W. A. 1982. Py- thium root rot: A barrier to yield of Pacific Northwest wheat. Wash. State College of Agric. Res. Bull. No. XB0913.

4. Cook, R. J., and Haglund, W. A. 1991. Wheat yield depression associated with conservation tillage caused by root pathogens in the soil not phytotoxins from the straw. Soil Biol. Biochem. 23:1125-1132.

5. Cook, R. J., Ownley, B. H., Zhang, H., and Vakoch, D. 2000. Influence of paired-row spacing and fertilizer placement on yield and root diseases of direct-seeded wheat. Crop Sci. 40:1079-1087.

6. Cook, R. J., Sitton, J. W., and Haglund, W. A. 1987. Influence of soil treatments on growth and yield of wheat and implications for control of Pythium root rot. Phytopathology 77:1192-1198.

7. Cook, R. J., and Veseth, R. J. 1991. Wheat Health Management. American Phytopathological Society, St. Paul, MN.

8. Hering, T. F., Cook, R. J., and Tang, W.-h. 1987. Infection of wheat embryos by Pythium species during seed germination and the influence of seed age and soil matric potential. Phytopathology 77:1104-1108.

9. Kim, D.-S., Cook, R. J., and Weller, D. M. 1997. Bacillus sp. L324-92 for biological control of three root diseases of wheat grown with reduced tillage. Phytopathology 87:551558.

10. King, E. O., Ward, M. K., and Raney, D. E. 1954. Two simple media for the demonstration of pyrocyanin and flurorescin. J. Lab. Clin. Med. 44:301-307.

11. Mathre, D. E., Cook, R. J., and Callan, N. W. 1999. From discovery to use: Traversing the world of commercializing biocontrol agents for plant disease control. Plant Dis. 83:972983.

12. Pierson, E. A., and Weller, D. M. 1994. Use of mixtures of fluorescent pseudomonads to suppress take-all and improve the growth of wheat. Phytopathology 84:940-947.

13. Raaijmakers, J. M., and Weller, D. M. 1998. Natural plant protection by 2,4diacetylphloroglucinol-producing Pseudomonas spp. in take-all decline soils. Mol. PlantMicrobe Interact. 11:144-152.

14. Roget, D. K., Venn, N. R., and Rovira, A. D. 1987. Reduction in Rhizoctonia root rot of direct drilled wheat by short-term chemical fallow. Aust. J. Exp. Agric. 27:425-430.

15. Smiley, R. W., Ogg, A. G., Jr., and Cook, R. J. 1992. Influence of glyphosate on Rhizoctonia root rot, growth, and yield of barley. Plant Dis. 76:937-942.

16. Smiley, R. W., and Patterson, L.-M. 1995. Winter wheat yield and profitability from Dividend and Vitavax seed treatments. J. Prod. Agric. 8:350-354.

17. Weller, D. M. 1988. Biological control of soilborne plant pathogens in the rhizosphere with bacteria. Annu. Rev. Phytopathol. 26:397-407.

18. Weller, D. M., and Cook, R. J. 1983. Suppression of take-all of wheat by seed treatments with fluorescent pseudomonads. Phytopathology 73:463-469.

19. Weller, D. M., and Cook, R. J. 1987. Increased growth of wheat by seed treatments with fluorescent pseudomonads, and implications of Pythium control. Can. J. Plant Pathol. 8:328-334. 